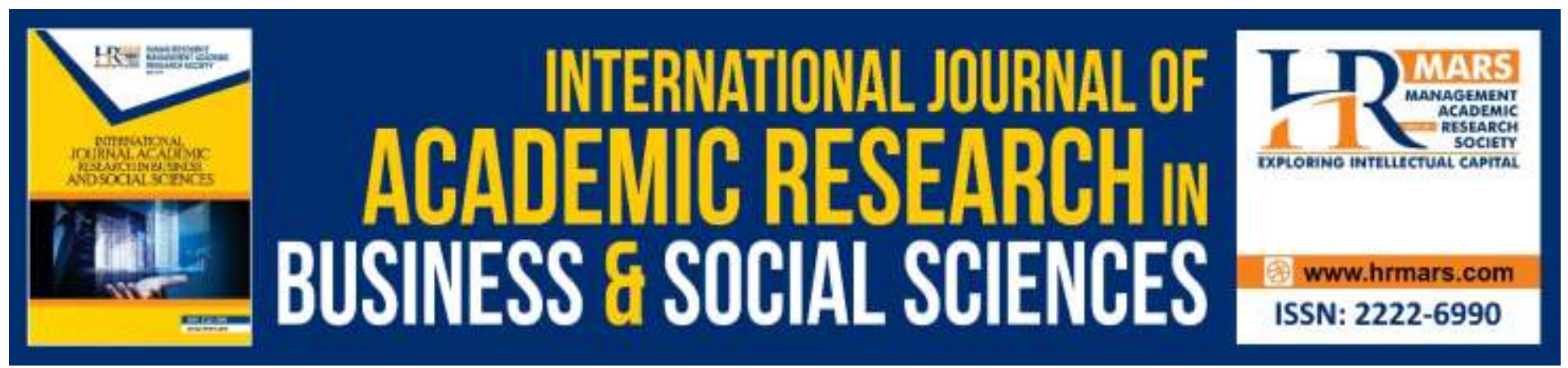

\title{
Islamic Bereavement Care Services Social Enterprise Model
}

\section{Maheran Katan, Nasreen Miza Hilmy Nasrijal}

To Link this Article: http://dx.doi.org/10.6007/IJARBSS/v10-i13/6883

DOI:10.6007/IJARBSS/v10-i13/6883

Received: 23 December 2019, Revised: 09 January 2020, Accepted: 27 January 2020

Published Online: 10 February 2020

In-Text Citation: (Katan \& Nasrijal, 2020)

To Cite this Article: Katan, M., \& Nasrijal, N. M. H. (2020). Islamic Bereavement Care Services Social Enterprise Model. International Journal of Academic Research in Business and Social Sciences, 10(13), 1-10.

Copyright: (C) 2020 The Author(s)

Published by Human Resource Management Academic Research Society (www.hrmars.com)

This article is published under the Creative Commons Attribution (CC BY 4.0) license. Anyone may reproduce, distribute, translate and create derivative works of this article (for both commercial and non-commercial purposes), subject to full attribution to the original publication and authors. The full terms of this license may be seen

at: http://creativecommons.org/licences/by/4.0/legalcode

Special Issue: Upstream Research in Business and Management: Towards Socio-Economic Prosperity, 2020, Pg. 1 - 10 http://hrmars.com/index.php/pages/detail/IJARBSS JOURNAL HOMEPAGE

Full Terms \& Conditions of access and use can be found at http://hrmars.com/index.php/pages/detail/publication-ethics 


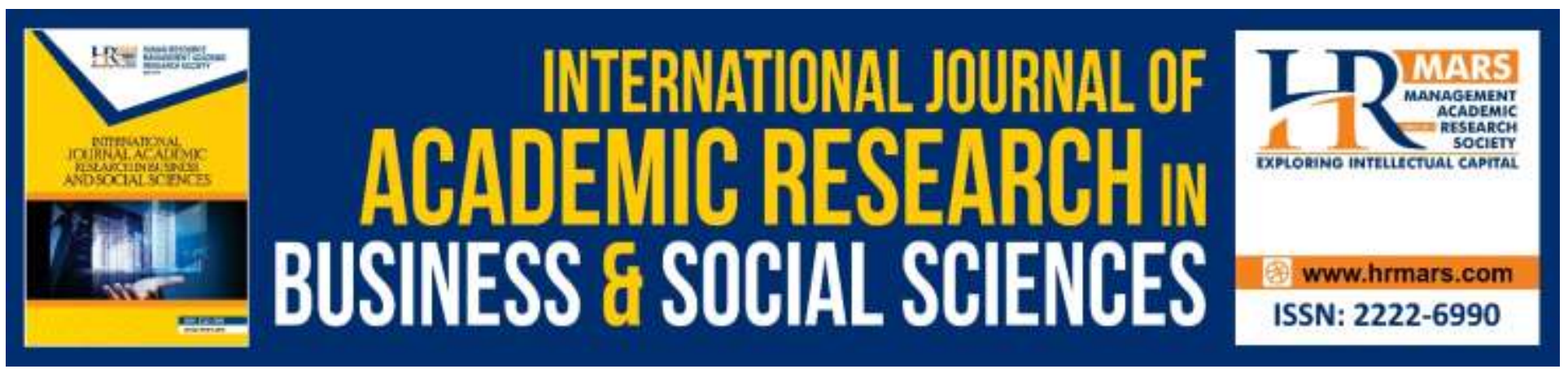

\title{
Islamic Bereavement Care Services Social Enterprise Model
}

\author{
Maheran Katan, Nasreen Miza Hilmy Nasrijal \\ Universiti Teknologi Mara, 110 Jalan Hang Tuah, 75300 Melaka, Malaysia \\ Email: maheran68@melaka.uitm.edu.my
}

\begin{abstract}
Urbanization and restructuring of residential areas in Malaysia have affected human relations. Full reliance on the traditional community-based bereavement care services (BCS) is no longer viable in view of the changes in social and community structure, resulting in the establishment of businessbased BCS. While BCS companies for non-Muslims seem to thrive, the same is not obvious for Islamic BCS despite the market is yet to be fully mined with Muslims making up 60\% of Malaysian population. Enhancing Islamic BCS industry requires a sound business model. Thus, the objective of this study is to develop an Islamic Bereavement Care Services Social Enterprise Model. Using qualitative approach, data is collected through semi-structured interviews with representatives of Islamic BCS companies. The model has four dimensions; motivation for involvement, actual involvement, value creation and sustainability. This study provides the link between Islamic BCS and commercialism through social business model.
\end{abstract}

Keywords: Islamic Bereavement Care Services, Social Enterprise Model, Islamic Pre-Need Funeral Plan, Qualitative

\section{Introduction}

Death is certain for every living creature. When death occurs, families will require professional help for bereavement care services (BCS) to facilitate bereaved families to make the necessary arrangements. BCS provides undesirable but vital services in relation to death: a means to dispose the deceased's body, processes of paying respect to the deceased, public notification that a death has occurred and emotional support system for the bereaved family and those most affected by the death.

Conventionally BCS was community-based, however, full reliance on the community to fulfil bereavement care services is affected by urbanization and restructuring of residential areas. Urbanization has affected human relations such as kinship, generational ties and household composition (Smith and Hanks, 2015). Human relations are further alienated due to the changes in the structure of residential areas in Malaysia. There are more housing estates, gated communities 
INTERNATIONAL JOURNAL OF ACADEMIC RESEARCH IN BUSINESS AND SOCIAL SCIENCES

Vol. 10, No. 13, Special Issue: Upstream Research in Business and Management: Towards Socio-Economic Prosperity. 2020, E-ISSN: 2222-6990 @ 2020 HRMARS

and high-rise buildings in urban Malaysia for privacy and security. Kuala Lumpur and Putrajaya recorded more than $50 \%$ increase in the percentage of flats, apartments, and condominiums (Zainudin \& Hussin, 2015). The changes in the social structure and community incidentally contribute towards the disintegration of close knit communities. Thus, with socio-cultural changes of the community resulting from urbanization, reliance on community-based BCS may not be practical in urbanized Malaysia.

Consequently, business-based BCS company has made its debut in Malaysia. BCS have been transformed into one-stop integrated package managed by business entities providing commercially efficient services. The financing of Islamic funeral that was traditionally done through the khairat kemation or mutual benevolent association (Muhamat, 2014) is replaced with a systematic Islamic pre-need funeral plans in which individuals lock-in a price for their service and spread the cost over several years. Table 1 shows the number of incorporated BCS companies in Malaysia as of August 2016. There are 92 incorporated BCS companies in Malaysia. Out of 92 companies, only two are for Muslims.

Table 1: Number of Muslim and Non-Muslim Registered BCS Companies

\begin{tabular}{|l|c|c|}
\hline State & No. of Companies (Muslim) & No. of Companies (Non-Muslim) \\
\hline Selangor & 1 & 18 \\
\hline Wilayah Persekutuan & 1 & 21 \\
\hline Other States & 0 & 51 \\
\hline Total & 2 & 90 \\
\hline
\end{tabular}

Source: Companies Commission of Malaysia (SSM)

My-Jenazah.com is one of the earliest Islamic BCS provider in Malaysia. Their services include disseminating news regarding the death of their subscribers to selected relatives using short messaging system (SMS), securing death registration and burial permit, washing and shrouding of the body, grave digging, hearse, burial ritual according to Syariah principles, performing prayers and recitation of the Quran, grave marker and funeral financial planning scheme. However, Islamic BCS does not appear to thrive despite the market being untapped with $60 \%$ of Malaysian population comprising of Muslims. More appalling is when some are flawed by dishonesty and lack of integrity as there were complaints of Islamic BCS provider absconding with the money paid by the contributors in Islamic funeral financial planning scheme (Harian, 2015). Charging exorbitant fees for funeral process management is also a concern as burying a deceased should not be a burden on the grieving family members.

There are two extreme types of business-based entity in capitalist system; on one extreme are profit-maximizing businesses, whose purpose is to create shareholders' value and at the end of the other extreme are non-profit organizations exist to fulfil social objectives. In between both ends are the hybrid social businesses that share the pursuit of revenue generation with commercial firms, but they also seek to achieve social goals. Social entrepreneurs identify opportunities to address an underserved social market and offers creative solutions to complex persistent social problems while giving returns to their shareholders. Surpluses generated by the social business are reinvested in the business and passed on to the target group of beneficiaries in such forms as lower prices, better service or greater accessibility (Yunus, Moingeon \& Lehmann-Ortega, 2010). 
Bull \& Ridley-Duff (2018) reviewed in great detail the existing social enterprise business model and concluded that there is a void in the existing social enterprise business model literature on the connection between its alleged hybridity of social enterprise and resulting business ethics. In similar vein, Mulyaningsih \& Ramadani (2017) argued that the existing social enterprise models are mostly perceived from the Western perspective and not based on religious points of view. It was reported that $35 \%$ of the 3 billion poor people in the world live in Muslim countries and empirical studies showed that less than optimal fulfilment of public facilities is a problem faced by Muslim countries (Hoque, Khan \& Mohammad, 2015). Since the justification for the existence of social enterprises is to reduce social problems (Okpara \& Halkias, 2011) such as poverty, social enterprises play an important role in poverty eradication. To enhance Islamic BCS industry, its business model needs to be developed. The dearth of studies on Islamic BCS enterprise evidently indicates the need for research to ensure the sustainability of the BCS. This would safeguard the sanctity of Islamic BCS and continuous adherence to Syariah. Thus, this paper aims to develop an Islamic Bereavement Care Services Social Enterprise Model.

For over two decades, social entrepreneurship has experienced a rapid rise in popularity in recent years resulting in the establishment of various social enterprises aimed at pursuing socially beneficial goals. Social enterprise literature appears to be a young research field and in need of further exploration especially on Malaysian Islamic social enterprise. A notable Malaysian study by Mhd Sarif, Sarwar and Ismail (2013) revealed four dimensions of Malaysian Muslim social enterprise; motivation for involvement, actual involvement, value creation and sustainability. However, there is a lack of studies on Malaysian Islamic BCS from social enterprise perspectives. In short, the link between Islamic BCS and commercialism through social business model is under-researched; thus, requiring further research.

\section{Methodology}

The objective of this study is to establish the Islamic Bereavement Care Services Social Enterprise Model. Qualitative research method is employed where semi-structured interviews were conducted with representatives from companies offering Islamic bereavement care services. Selection of the companies were based on the search conducted the Companies Commission of Malaysia (Table 1 above). Upon obtaining approval and securing appointments with the directors of the companies, semi-structured interviews were conducted. The purpose of the semi-structure interview is to gain insights and understanding on the business model of the interviewees. Both interviewees (Interviewee 1 and Interviewee 2) agreed to participate in the interview and the interviews were audio-recorded with the permission of the interviewees. The interview followed a similar format, with variations to take account of the different approaches of their businesses. All interviews were conducted in person and in the offices of the respondents. When the interviewees interviewed spoke in the Malay language, the translation was made, and a reliability check for the translation was done. Questions were asked to explore the dynamics of their business. Semistructured questions were developed based on elements identified from Mhd Sarif, Sarwar and Ismail (2013). The data were analysed according to the thematic analysis for four themes: 1) motivation for involvement, 2) actual involvement, 3) value creation and 4) sustainability. 
INTERNATIONAL JOURNAL OF ACADEMIC RESEARCH IN BUSINESS AND SOCIAL SCIENCES

Vol. 10, No. 13, Special Issue: Upstream Research in Business and Management: Towards Socio-Economic Prosperity. 2020, E-ISSN: 2222-6990 @ 2020 HRMARS

\section{Results}

Both companies have been in business for less than 10 years and employing less than 20 employees. The major findings are summarized as follows:

Motivation for involvement: Death is considered morbid by most and there is a stigma attached to those involve in the business of death. Despite the negative connotation associated with business of death, these two companies chose to set up a business offering Islamic bereavement care services. The tagline of both companies is "Cashless Funeral". Their main motivation to provide BCS is to help ease the financial burden faced by the family of the deceased. The cost of funeral in Malaysia has escalated and the cost will soar if the deceased is to be buried far from the place of death. The transportation cost would fluctuate depending on distance, place and availability of transport. Both interviewees mentioned the high cost that the family has to pay especially if it involved transporting the body of the deceased. Thus, by subscribing into the package offered by these companies, the subscriber has taken care of the financial aspect of his/her funeral. Moreover, the interviewees emphasized that their services are complementing the existing khairat kematian scheme handled by mosque committees. Interviewee 1 mentioned that;

"We offer Islamic pre-need funeral package for complete Islamic funeral management, personal accidence takaful protection and estate management services. Once a person joins our scheme, the family does not have to pay for the funeral expenses because that person has contributed a predetermined amount of money monthly to take care of the funeral expenses when the time comes. We will cover all the cost including the transportation cost of bringing the deceased to his/her hometown. We are not competing or trying to take over the role of the khairat kematian handled by the mosques... some of the mosques have outsourced the funeral management to us".

Interviewee 2 concurred that;

"We are motivated to provide bereavement care services to help ease financial burden to the family of the deceased. Considering the modernized and urbanized living condition nowadays, there is a need for our services to complement the traditional khairat kematian scheme. The khairat kematian scheme is handled by community committee of a kariah (area) and the kariah has financial constraints. Especially if a person dies outside his/her residential area. For example, if a person dies in Perlis and the family is in Melaka. The mosque committee in Melaka won't arrange the transportation to bring back the body, but our package covers all costs including transportation cost".

Both interviewees highlighted their intention to foster the muamalat activity which is very much encouraged in Islam. They highlighted how NV Multi Corp successfully transformed the traditional Chinese funeral into a multimillion business venture. NV Multi Corp is the first BCS provider to list their stock in Bursa Malaysia in 2000 and subsequent listing of Nirvana Asia in Hong Kong Stock Exchange in 2015. The same phenomena can be applied to Muslim community. Both interviewees agreed that by running this business they fulfilled the fardu kifayah as one of religious obligations and at the same time cultivating the muamalat elements in seeking wealth through business transactions.

Another issue related to death is estate management, which is included in the package. Solving the problem of frozen assets was mentioned by interviewee 1 as one of the reasons that motivated them to initiate in this business;

"There is tremendous amount of frozen assets in Malaysia due to not having proper estate management. Frozen assets are such a waste because these assets cannot be used for productive 
INTERNATIONAL JOURNAL OF ACADEMIC RESEARCH IN BUSINESS AND SOCIAL SCIENCES

Vol. 10, No. 13, Special Issue: Upstream Research in Business and Management: Towards Socio-Economic Prosperity. 2020, E-ISSN: 2222-6990 @ 2020 HRMARS

purposes. Thus, we aid on estate management in our package. With proper estate management, the assets left by the deceased can be distributed among the rightful heir in efficient and timely manner".

Actual Involvement: The core business for these Islamic BCS is offering Islamic pre-need funeral plan whereby when customers buys the funeral scheme they will pay monthly or yearly contribution fees and in the event of their death, these BCS companies will perform the funeral process without changing any payment to the family members. They apply the takaful concept in their business. Takaful is based on mutual co-operation and shared responsibility among participants who jointly agree to contribute a sum of money in a form of donation into a shared pool with the intention to help each other to reduce risk (Abdullah, 2012). Interviewee 1 explained their nature of business and the function of takaful;

"This business is sort of risk free to our customers because the scheme is backed by takaful protection. A big portion of monthly contribution from the customers is used as contribution to the takaful company. In the event of death, the takaful company will pay for the cost of funeral and if death is caused by accident, the family will get personal accident takaful compensation. Since it is backed by a takaful plan, the customers are guaranteed of the stipulated payments. To give you an example, our basic scheme costs RM5 per month. In the event of death, the member will be given a complete funeral management worth RM5,000, takaful personal accident coverage of RM 15,000 and assistance in estate management. How is it possible? If a member pays RM60 for 30 years, it will add up to only RM1,800 but we will pay RM5,000 upon death. How could we make money? This is the beauty of our business, we are basically free of liability because we transfer out liability to takaful company. A portion of the monthly payment is paid to takaful company. When a death occurs, our company will pay RM5,000 upfront and subsequently we claim from takaful. In other words, the takaful company guarantees the funeral scheme".

Value Creation/Societal Development: Defourny and Nyssens (2017) defined social enterprises as companies developing business activities for a social purpose or mission. Both interviewees considered their organization as social enterprise. Interviewee 1 said;

"Our business is a social enterprise because we would like to solve social problem i.e. there are places whereby there is nobody who can handle the funeral processes. So, we provide the services. Our bottom line is profit, we are not NGOs. In short, we provide services to help the Muslim prepare for their funeral, however we do not operate like the "khairat kematian" scheme. We incorporate the business elements; thus, our operation is more efficient, and we are accountable to provide the services promised".

The same justification was given by Interviewee 2;

"We can be considered as a social enterprise because we are conducting a business for community benefits. We operate like any other businesses, but we are reinvesting the profit into charitable organizations such as tahfiz centre for Rohingya refugees and other programs for the community such as flood relief drive".

Both companies have successfully integrated economic and social purposes in their business. This integration is the key characteristic of social entrepreneurs (Wry \& York, 2017). Rising cost of funeral has become a social problem in some countries. Woodthorpe, Rumble and Valentine (2013) reported that there are people in the United Kingdom who cannot afford to pay for the funeral of a deceased family member and require some form of state assistance. The state has to absorb the cost of funeral through Social Fund Funeral Payment. Another concern is the issue of pensioner poverty 
INTERNATIONAL JOURNAL OF ACADEMIC RESEARCH IN BUSINESS AND SOCIAL SCIENCES

Vol. 10, No. 13, Special Issue: Upstream Research in Business and Management: Towards Socio-Economic Prosperity. 2020, E-ISSN: 2222-6990 @ 2020 HRMARS

where pensioners are living in poverty. Given the ageing of Malaysian population, pensioner poverty will be a reality in Malaysia, and if these burgeoning ageing pensioners do not subscribe to pre-need funeral plan, they will become a burden to the government. In fact, both interviewees mentioned that they have conducted funeral process for those who could not afford funeral and the cost are incurred by state institutions such as zakat centres or BaitulMal. Thus, the Islamic BCS companies contribute to solving the social problem by offering a platform for Muslims to be financially prepared for their funeral arrangements. Apart from facilitating Islamic funeral through Islamic pre-need funeral scheme, Interviewee 1 has prepared the Standard Operating Procedures (SOP) on Islamic funeral to be used by all states in Malaysia, subject to the approval of the State Islamic Religious Council. Another SOP being prepared is on funeral management for students in institute of higher learning including international students. With standardized procedures and cost structures, these SOPs are important to ensure the funeral process in the Muslim community is free of non-Shariah compliance practices. Furthermore, these companies regularly conduct workshops on funeral management among youngsters to ensure the availability of successors for Islamic funeral managers.

Sustainability: To build longevity in social enterprise agendas, commercial sustainability is vital. An avenue for social enterprises to successfully align the achievement of social goals with organizational sustainability is through smart partnership with various stakeholders (Jenner \& Fleischman, 2017). Both interviewees have taken necessary measures with stakeholders to create a valuable product for the Muslim community. Interviewee 1 explained;

"We collaborated with Angkasa (the National Cooperative Movement of Malaysia) and Rosgate Insurance Brokers Sdn. Bhd. Angkasa has 8.5 million members. This smart collaboration will broaden our customer base. The cooperative also benefited when its members joined our scheme because we give introducer fees to the cooperative. In terms of promotion, we have a link with Koperasi Editor Kanan Akhbar, a cooperative society for newspaper editors".

Interviewee 2 concurred by saying;

"We did strategic partnership with cooperative bodies such as National Union of Teaching Profession (NUTP). In order to give the best service, we form a link with the Malaysian Imam Association (Persatuan Imam seMalaysia). For promotional purposes, we collaborated with Yayasan Artis. We are also involved in core-adjacent business such as being the optional package for insurance scheme offered by insurance company. For example, for life insurance, customers can add-on our funeral scheme. In addition, we are conducting the Islamic funeral management courses in order to ensure a pool of succession funeral managers".

The purpose of this study is to develop an Islamic Bereavement Care Services Social Enterprise Model. Summarizing findings from the semi-structured interviews, the proposed model is as illustrated in Figure 1 below. 
INTERNATIONAL JOURNAL OF ACADEMIC RESEARCH IN BUSINESS AND SOCIAL SCIENCES

Vol. 10, No. 13, Special Issue: Upstream Research in Business and Management: Towards Socio-Economic Prosperity. 2020, E-ISSN: 2222-6990 @ 2020 HRMARS

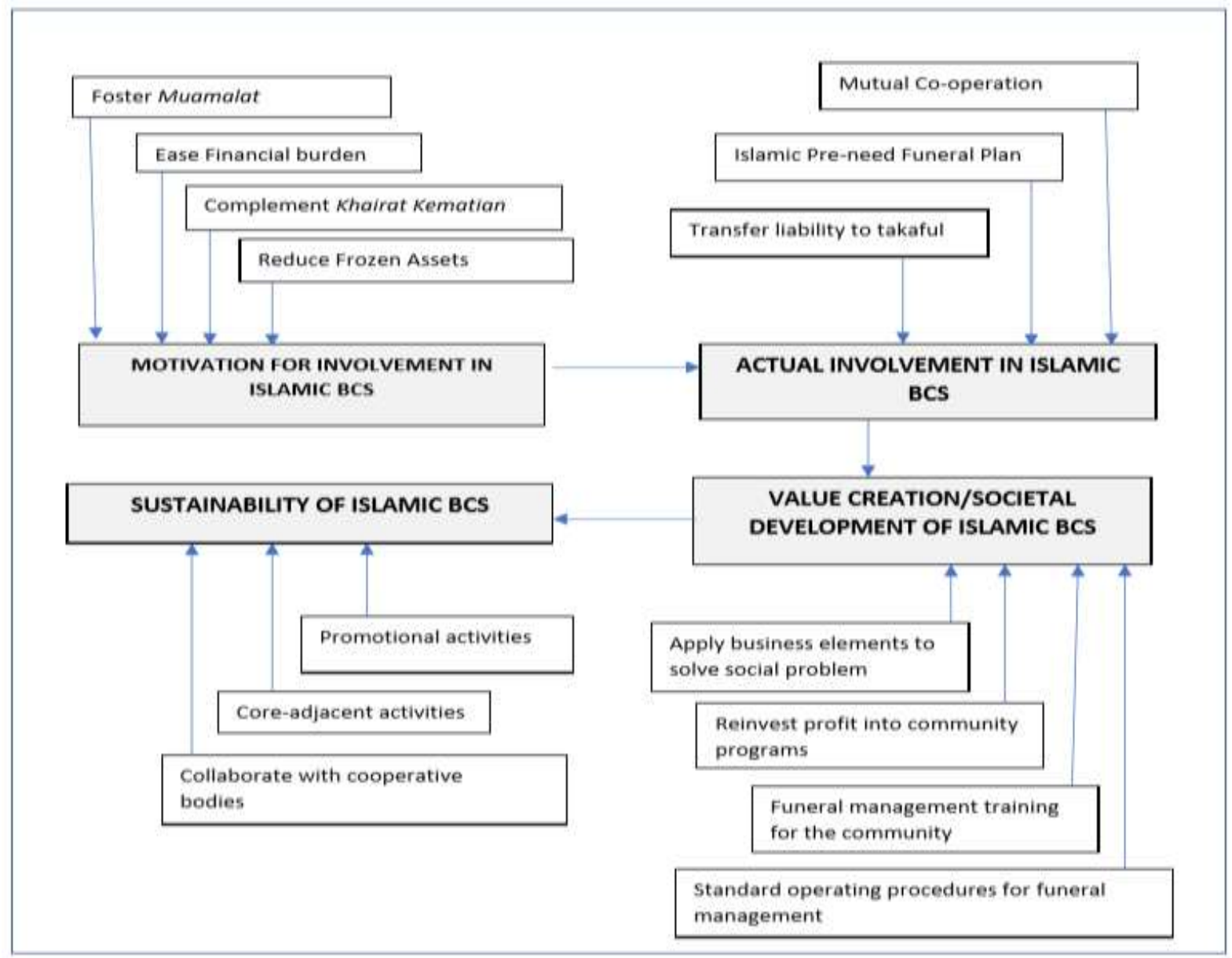

Figure 1: Islamic Bereavement Care Services Social Enterprise Model.

\section{Conclusion}

The foundation of the Islamic BCS Social Enterprise Model is on the concept of shared contributions by members of the schemes to help those in the community who are in need. This is in line with the Holy Quran and the sayings of Prophet Muhammad S.A.W.;

Allah said, "Help Ye one another in righteousness and piety but help ye not one another in sin and rancor..." (Al Maidah: 2).

The place of relationships and feelings of people with faith, between each other, is just like the body; when one of its parts is afflicted with pain, then the rest of the body will be affected. (Narrated by Imam Al-Bukhari and Imam Muslim).

The findings confirmed that the Islamic BCS companies' main objective is to solve social problem using business approach. This is similar with the objectives of social enterprise reported in the literature (Smallbone et al., 2001; Haugh, 2006; Weaver, 2018). In terms of actual involvement, they are applying the takaful concept to protect their customer's interest. Takaful is a mechanism that can be used to bring benefits for the betterment of the society (Dahnoun \& Alqudwa, 2018). In relation to value creation, Islamic BCS social entrepreneurs help in societal development by introducing the Islamic pre-need funeral scheme which is a sustainable and innovative means to solve social problem in terms of the potential financial difficulties faced by Muslims to arrange for funeral 
INTERNATIONAL JOURNAL OF ACADEMIC RESEARCH IN BUSINESS AND SOCIAL SCIENCES

Vol. 10, No. 13, Special Issue: Upstream Research in Business and Management: Towards Socio-Economic Prosperity. 2020, E-ISSN: 2222-6990 @ 2020 HRMARS

of the loved ones. This is in accordance with the concept of social entrepreneurship (Mahfuz Ashraf, Razzaque, Liaw, Ray, \& Hasan, 2018). Moreover, Islamic BCS social entrepreneurs standardized the traditional funeral management by incorporating standard operating procedures for Islamic funeral. Standard operating procedures resulted in formalized tasks that are easier to adopt and learn (Ketokivi, Turkulainen, Seppala, Rouvinen, \& Ali-Yrkkö, 2017). The standard operating procedures with step-by-step guidance on how to perform Islamic funeral would make the process easier to perform and would attract more individuals to get involve in funeral management. Thus, ensuring the availability of funeral manager successors in the community. Finally, Islamic BCS social entrepreneurs are working on sustaining their business venture by forming strategic collaboration with cooperative societies, promoting their core business and offering core-adjacent businesses. Key partners and collaboration initiatives have been identified as value creation because entrepreneurs never create value in a black-box but rather in the solid collaboration with diverse stakeholders (Schaltegger, Beckmann, \& Hockerts, 2018).

This study contributed in providing empirical research to identify the critical constructs for understanding value creation of a new venture; i.e. Islamic BCS social entrepreneurship. Future research may consider studying the proper monitoring systems by the relevant governing bodies in order to safeguard the interest of parties involved in this industry.

\section{Acknowledgements}

Sincere appreciation goes to Kementerian Pendidikan Malaysia (KPM), Fundamental Research Grant Scheme (FRGS) [600-IRMI/FRGS 5/3 (28/2016)], RMI, and UiTM for the support given to this research endeavour.

\section{References}

Abdullah, S. (2012). Risk management via Takaful from a perspective of Maqasid of Shariah. ProcediaSocial and Behavioral Sciences, 65, 535-541.

Bull, M., \& Ridley-Duff, R. (2018). Towards an appreciation of ethics in social enterprise business models. Journal of Business Ethics, 1-16. doi:10.1007/s10551-018-3794-5

Dahnoun, M., \& Alqudwa, B. (2018). Islamic Insurance: An Alternative to Conventional Insurance. American Journal of Humanities \& Islamic Studies, 1(1), 1-8.

Defourny, J., \& Nyssens, M. (2017). Fundamentals for an international typology of social enterprise models. International Journal of Voluntary and Non-profit Organizations, 28(6), 2469-2497.

Haugh, H. (2006). Social enterprise: Beyond economic outcomes and individual returns. In Social entrepreneurship. Palgrave Macmillan, London.

Hoque, N., Khan, M. A., Mohammad, K. D. (2015). Poverty alleviation by zakah in a transitional economy: Asmall business entrepreneurial framework. Journal of Global Entrepreneurship Research, 5(7),1-20.

Jenner, P., \& Fleischman, D. (2017). On the road to social enterprise sustainability: A value co-creation pathway. Proceedings of the 6th EMES International Research Conference on Social Enterprise. EMES International Research Network.

Ketokivi, M., Turkulainen, V., Seppala, T., Rouvinen, P., \& Ali-Yrkko, J. (2017). Why locate manufacturing in a high-cost country? A case study of 35 production location decisions. Journal of Operations Management, 49, 20-30. 
INTERNATIONAL JOURNAL OF ACADEMIC RESEARCH IN BUSINESS AND SOCIAL SCIENCES

Vol. 10, No. 13, Special Issue: Upstream Research in Business and Management: Towards Socio-Economic Prosperity. 2020, E-ISSN: 2222-6990 @ 2020 HRMARS

Ashraf, M., Razzaque, M. A., Liaw, S. T., Ray, P. K., \& Hasan, M. R. (2018). Social business as an entrepreneurship model in emerging economy: Systematic review and case study. Management Decision. doi:10.1108/MD-04-2017-0343.

Sarif, M. S., Sarwar, A., \& Ismail, Y. (2013). Practice of Social Entrepreneurship among the Muslim Entrepreneurs in Malaysia. Middle-East Journal of Scientific Research, 14 (11), 1463-1470.

Mulyaningsih, H. D., \& Ramadani, V. (2017). Social Entrepreneurship in An Islamic Context. In Entrepreneurship and Management in an Islamic Context (pp. 143-158). Springer, Cham.

Muhamat, A. A. (2014). Transforming the khairat kematian (mutual benevolent association) to mini cooperative. DimensiKoop, 43, 25-28

Okpara, J. O., \& Halkias, D. (2011). Social entrepreneurship: an overview of its theoretical evolution and proposed research model. International Journal of Social Entrepreneurship and Innovation, 1(1), 4-20.

Schaltegger, S., Beckmann, M., \& Hockerts, K. (2018). Collaborative entrepreneurship for sustainability. Creating solutions in light of the UN sustainable development goals. International Journal of Entrepreneurial Venturing, 10(2), 131-152.

Harian, S. (2015). Syarikat urus jenazah ghaib, 1 Okt 2015.

Smallbone, D., Evans, M., Ekanem, I., \& Butters, S. (2001). Researching social enterprise: Final report to the small business service. Centre for Enterprise and Economic Development Research, Middlesex University Business School, Middlesex University, UK.

Smith, D. J., \& Johnson-Hanks, J. A. (2015). Special Issue: Population and Development: Comparative Anthropological Perspectives. St Comp Int Dev, 50,433-454.

Weaver, R. L. (2018). Re-Conceptualizing Social Value: Applying the Capability Approach in Social Enterprise Research. Journal of Social Entrepreneurship, 9(2), 79-93.

Wry, T., \& York, J. G. (2017). An identity-based approach to social enterprise. Academy of Management Review, 42(3), 437-460.

Woodthorpe, K., Rumble, H., \& Valentine, C. (2013). Putting 'the grave'into social policy: state support for funerals in contemporary UK society. Journal of Social Policy, 42(3), 605-622.

Yunus, M., Moingeon, B., \& Lehmann-Ortega, L. (2010). Building social business models: lessons from the Grameen experience. Long range planning, 43(2), 308-325.

Zainudin, A. Z., \& Hussin, K. (2015). The cooperative-collective sharing arrangement of gated communities in Malaysia. Property Management, 33(4), 330-347. 